\title{
Hubungan Pemberian Air Susu Ibu (ASI) dengan Tumbuh Kembang Balita
}

\author{
Restu Octasila*, Mardi Yana, Muniswatin \\ Prodi Diploma 3 Kebidanan Sekolah Tinggi IImu Kesehatan Banten \\ *Email korespondensi: restu.octasila@gmail.com
}

Article Info

Article history:

Submitted: 2019-02-26

Accepted: 2019-04-16

Published: 2019-04-22

Keywords:

Exclusive

Breastfeeding;

Growth;

Development.

\section{ABSTRACT}

Growth and development of children from birth to adulthood, so it needs to be done early detection of developmental deviations. The results of the survey conducted at Puskesmas Parung Panjang there are $52(0.5 \%)$ toddlers who get help MP-ASI because weight is very thin. Exclusive breastfeeding nutrition program at UPT Parung Panjang in 2016 which target $90 \%$, but only reached $35.77 \%$. The research method used is analytical descriptive with Cross Sectional approach with sampling technique with accidental sampling. The population used were children aged 6-60 months in Posyandu Bakti Husada, Puskesmas Parung Panjang with a sample of 41 respondents. The tool used is KPSP to detect the development, and table / chart BB/U and TB/U to measure the growth of children under five. Result of research from 41 respondents got univariate result of good growth status as much $87,8 \%$ and less good as much as $12.2 \%$. The result of bivariate test showed statistically there was a significant relationship ( $p$ value $<0.05$ ) between breastfeeding and infant growth. Conclusions and suggestions of the relationship of exclusive breastfeeding to the growth of babies, for mothers are expected to provide exclusive breastfeeding to babies or balitanya and stimulate development early on.

\section{PENDAHULUAN}

Pertumbuhan dan perkembangan anak dimulai sejak lahir hingga mencapai dewasa. Pertumbuhan ditandai oleh perubahan ukuran badan anak, dari kecil menjadi besar dan semakin besar. Sedangkan perkembangan ditandai dengan kemampuan, yaitu kemampuan terbatas pada waktu lahir seperti tersenyum, berbicara, berjalan, berlari, belajar dan bergaul dikemudian hari. ${ }^{(1)}$

Indikator keberhasilan SDG's diterjemahkan dalam enam poin, yakni peningkatan ASI eksklusif, makanan pada ibu hamil serta anak, menekan jumlah balita pendek, ibu hamil penderita anemia, kurang energi, dan balita kurus. "Tujuan dalan SDG's sudah ada dalam RPJMN 2015-2019 bidang kesehatan," kata Direktur Bina Gizi Kementerian Kesehatan (Kemenkes) RI Doddy Izwardy. Pemilihan enam poin dalam bidang gizi terkait laporan Global Nutrition Report tahun 2014 yang menyatakan Indonesia merupakan satu dari 117 negara yang menderita tubuh pendek (stunting), kurus (wasting), dan obesitas akibat ketidakseimbangan asupan gizi. (2)

Menurut UNICEF tahun 2011 didapat data masih tingginya angka kejadian gangguan pertumbuhan dan perkembangan pada anak usia balita khususnya gangguan perkembangan motorik didapatkan $(27,5 \%)$ atau 3 juta anak mengalami gangguan. Balita di Indonesia sekitar 16\% dilaporkan mengangalami gangguan 
perkembangan berupa gangguan kecerdasan akibat gangguan perkembangan otak, gangguan pendengaran dan gangguan motorik (Depkes RI, 2006). Pada tahun 2010 gangguan pertumbuhan dan perkembangan pada anak di Indonesia mencapai 35,7\% dan tergolong dalam masalah kesehatan masyarakat yang tinggi menurut acuan WHO karena masih diatas 30\% (Riskesdas, 2010). Data angka kejadian keterlambatan perkembangan umum belum diketahui dengan pasti, namun diperkirakan sekitar 1-3\% anak di bawah usia 5 tahun mengalami keterlambatan perkembangan umum. ${ }^{(3)}$

Pemberian ASI eksklusif untuk bayi yang berusia $<6$ bulan secara global dilaporkan kurang dari $40 \% .{ }^{(5)}$ Secara nasional cakupan ASI untuk bayi sampai umur 6 bulan mengalami fluktuasi, yaitu $24,3 \%$ pada tahun 2008, kemudian meningkat pada tahun 2009 menjadi 34,3\% dan menurun pada tahun 2010 menjadi 33,0\%. ${ }^{(1)}$

Hasil survey yang di lakukan di wilayah Puskesmas Parung Panjang, terdapat jumlah balita sebanyak 9386 balita. Dengan capaian ASI Eksklusif program gizi di UPT Parung Panjang tahun 2016 yang targetnya 90\%, namun hanya tercapai $35.77 \%$ dan kesenjangannya 54.23\%. Sedangkan balita yang mendapatkan bantuan MP-ASI dikarenakan status gizinya kurang dan beberapa terdapat perkembangannya belum sesuai dengan usianya terdapat 52 balita (0.5\%). Dimana dari 7 desa yang menjadi wilayah kerja Puskesmas Parung Panjang, desa yang paling banyak mendapat bantuan tersebut adalah Desa Cibunar, 14 balita (0.96\%) dari 1447 seluruh balita di desa tersebut. Setelah dikaji, di Posyandu Bakti Husada di Desa Cibunar, terdapat 115 balita dan ada 3 balita (2.6\%) dengan kategori pertumbuhannya sangat kurus.

Gangguan atau masalah penyimpangan yang sering timbul dalam perkembangan anak meliput gangguan gerak kasar, gerak halus, bicara dan bahasa, sosialisasi dan kemandirian. Sehingga perlu dilakukan deteksi dini penyimpangan perkembangan. Melakukan deteksi dini penyimpangan perkembangan artinya melakukan skrining atau mendeteksi secara dini adanya penyimpangan perkembangan balita termasuk menindaklanjuti setiap keluhan orangtua terhadap masalah perkembangan balita, artinya melakukan tindakan koreksi dengan memanfaatkan plastisitas otak anak untuk memperbaiki penyimpangan perkembangan pada seorang anak agar perkembangannya kembali normal atau penyimpangannya tidak semakin berat. Apabila balita perlu dirujuk, maka rujukan juga harus dilakukan sedini mungkin sesuai dengan indikasi. (4) Karena perkembangan pada fase awal ini akan menentukan perkembangan fase selanjutnya. Kekurangan pada salah satu aspek perkembangan dapat mempengaruhi fase lainnya. ${ }^{(5)}$

Berdasarkan uraian di atas dapat disimpulkan bahwa pemberian ASI Eksklusif sangat berpengaruh terhadap tumbuh kembang balita. Oleh karena itu, tumbuh kembang harus menjadi perhatian bagi pemerintah, tenaga kesehatan, dan masyarakat khususnya supaya anak Indonesia dapat mencapai kesehatan yang optimal. Tujuan penelitian ini melihat gambaran tumbuh berdasarkan BB, TB serta Lingkar Kepala dan kembang dengan menggunakan KPSP, pemberian ASI Ekslusif serta hubungan antara pemberian ASI dengan tumbuh kembang balita.

\section{METODE PENELITIAN}

Desain penelitian ini adalah Cross Sectional dengan dan jumlah sampel yang didapat sebanyak 41 balita di Posyandu Bakti Husada wilayah kerja Puskesmas Parung Panjang berdasarkan One-sample situations - Hypothesis tests for a 
population proportion (two-sides test). Data yang digunakan adalah data primer. Data primer penelitian ini adalah data yang didapat langsung dari responden dengan menggunakan kuesioner yang mengkaji tentang usia bayi, berat badan balita, tinggi badan balita, serta pertanyaan langsung tentang perkembangan balita yang mengacu pada Kuesioner Pra Skrining Perkembangan (KPSP). Analisis data univariat menggunakan uji persentase kejadian dan analisis data bivariat menggunakan uji chi square.

\section{HASIL PENELITIAN}

Penelitian ini dilaksanakan di Wilayah Kerja Puskesmas Parung Panjang khususnya di Posyandu Bakti Husada, Dessa Cibunar pada tanggal 10 Agustus 2018, dan mendapat 41 sampel.

\section{Analisa Univariat}

Tabel 1. Distribusi Frekuensi Status Tumbuh Kembang Balita di Wilayah Kerja Puskesmas Parung Panjang Tahun 2018

\begin{tabular}{|c|c|c|}
\hline \multirow{2}{*}{\multicolumn{3}{|c|}{$\begin{array}{c}\text { Variabel } \\
\text { Berat Badan/ Umur (BB/U) }\end{array}$}} \\
\hline & & \\
\hline Normal (-2 SD s.d 2 SD) & 36 & 87.8 \\
\hline Kurus (<-2 SD s.d -3 SD) & 4 & 9.8 \\
\hline Sangat Kurus (<-3 SD) & 1 & 2.4 \\
\hline \multicolumn{3}{|l|}{ Tinggi Badan/ Umur (TB/U) } \\
\hline Normal (-2 SD s.d 2 SD) & 35 & 85.4 \\
\hline Pendek (<-2 SD s.d -3 SD) & 2 & 4.9 \\
\hline Tinggi (>3 SD) & 4 & 9.8 \\
\hline \multicolumn{3}{|l|}{ Lingkar Kepala } \\
\hline Baik (-2 SD s.d 2 SD) & 39 & 95.1 \\
\hline Kurang (<-2 SD) & 2 & 4.9 \\
\hline \multicolumn{3}{|l|}{ Status Pertumbuhan } \\
\hline Baik & 36 & 87.8 \\
\hline Kurang Baik & 5 & 12.2 \\
\hline \multicolumn{3}{|l|}{ Status Perkembangan dengan KPSP } \\
\hline Sesuai (9-10) & 37 & 90.2 \\
\hline Meragukan (7-8) & 4 & 9.8 \\
\hline Menyimpang $(\leq 6)$ & 0 & 0,0 \\
\hline \multicolumn{3}{|l|}{ Status Tumbuh Kembang } \\
\hline Baik & 36 & 87.8 \\
\hline Kurang Baik & 5 & 12.2 \\
\hline
\end{tabular}

Sumber: Data Primer, 2018

Berdasarkan tabel 1 berat badan menurut umur dengan kategori sangat kurus terdapat $2.4 \%$, kategori kurus terdapat $9.8 \%$, dan kategori normal terdapat $87.8 \%$. Masih ada angka kategori sangat kurus dari hasil penelitian yaitu sebesar $2.4 \%$. Berdasarkan tinggi badan menurut umur dengan kategori normal terdapat $85.4 \%$, kategori pendek terdapat $4.9 \%$, dan kategori tinggi terdapat $9.8 \%$. berdasarkan hasil pengukuran lingkaran kepala, masih terdapat $4.9 \%$ dengan lingkar kepala kurang, sebagian besar memiliki lingkar kepala normal $95.1 \%$

Berdasarkan status pertumbuhan baik terdapat $87.8 \%$ dimana hasil tersebut didapatkan apabila BB/U, TB/U, dan Lingkar Kepala (LK) dalam kategori normal. 
Sedangkan terdapat $12.2 \%$ balita dengan status pertumbuhan kurang baik, yang dilihat berdasarkan ada salah satu atau lebih BB/U, TB/U, atau Lingkar Kepala (LK) memiliki kategori di bawah normal (pendek, sangat pendek, kurus, atau sangat kurus).

Berdasarkan status perkembangan menggunakan Kuesioner Pra Skrining Perkembangan (KPSP) dengan kategori sesuai (9-10) terdapat $90.2 \%$ sedangkan kategori meragukan terdapat $9.8 \%$.

Tabel 2. Distribusi Frekuensi Pemberian Air Susu Ibu (ASI) di Wilayah Kerja Puskesmas Parung Panjang

\begin{tabular}{llr}
\hline \multicolumn{1}{c}{ Pemberian ASI } & Frekuensi & $\%$ \\
\hline Eksklusif & 28 & 68.3 \\
Tidak Eksklusif & 13 & 31.7 \\
\hline
\end{tabular}

Sumber: Data Primer, 2018

Berdasarkan tabel 2 dapat diketahui distribusi frekuensi pemberian ASI eksklusif pada balita selama 0-6 bulan terdapat $68.3 \%$, sedangkan tidak eksklusif terdapat $31.7 \%$. Menurut WHO, definisi ASI eksklusif adalah bahwa bayi hanya menerima ASI dari ibu, atau pengasuh yang diminta memberikan ASI dari ibu, tanpa penambahan cairan atau makanan padat lain, kecuali sirup yang berisi vitamin, suplemen mineral atau obat.

\section{Analisis Bivariat}

Tabel 3. Hubungan Pemberian Air Susu Ibu (ASI) terhadap Tumbuh Kembang Balita di Wilayah Kerja Puskesmas Parung Panjang

\begin{tabular}{lcccccc}
\hline \multirow{2}{*}{ Pemberian ASI } & \multicolumn{3}{c}{ Status Tumbuh Kembang } & \multirow{2}{*}{ Nilai $\mathbf{p}$} & Risk Estimate \\
\cline { 2 - 5 } & Baik & $\%$ & $\begin{array}{c}\text { Kurang } \\
\text { baik }\end{array}$ & $\%$ & & \\
\hline Ekslusif & 27 & 96.4 & 1 & 3.6 & 0.02 & 12.0 \\
Tidak Ekslusif & 9 & 69.2 & 4 & 30.8 & & $(1.1-121.8)$ \\
\hline \multicolumn{1}{c}{ Total } & 36 & 87.8 & 5 & 12.2 & & \\
\hline
\end{tabular}

Sumber: Data Primer, 2018

Berdasarkan tabel 3 dapat diketahui bahwa terdapat $96.4 \%$ balita yang diberi ASI secara eksklusif dengan status tumbuh kembang baik, sedangkan terdapat $30.8 \%$ balita yang diberi ASI tidak eksklusif dengan status tumbuh kembang kurang baik. Berdasarkan uji statistic, didapatkan nilai $P$ value $0.02, P$ Value $<\alpha(0.05)$ artinya ada hubungan yang signifikan antara pemberian Air Susu Ibu (ASI) dengan status tumbuh kembang balita. Pemberian Air Susu Ibu (ASI) memiliki peluang risiko 12.0 kali (95\% $\mathrm{Cl}: 1.1-121.8)$ terhadap tumbuh kembang balita yang kurang baik.

\section{PEMBAHASAN}

Berdasarkan tabel 1 berat badan menurut umur dengan kategori sangat kurus terdapat $2.4 \%$, kategori kurus terdapat $9.8 \%$, dan kategori normal terdapat $87.8 \%$. Kategori tersebut didapat dari tabel antopometri BB/U menurut Kementrian Kesehatan Republik Indonesia 2010. Masih ada angka kategori sangat kurus dari hasil penelitian 
yaitu sebesar $2.4 \%$. Hal ini didukung oleh prevalensi status gizi buruk atau balita yang memiliki berat badan sangat kurus berdasarkan pengukuran Berat Badan menurut Umur (BB/U) tahun 2013 secara nasional terdapat 5.7\% sedangkan di Jawa Barat sendiri terdapat $4.4 \%{ }^{7}$. Hal tersebut didukung pula berdasarkan data klinik gizi yang ada di Puskesmas Parung Panjang tahun 2016 menyebutkan bahwa balita yang mendapatkan bantuan MP-ASI dikarenakan status gizinya kurang dan beberapa terdapat perkembangannya belum sesuai dengan usianya terdapat 52 balita $(0.5 \%)$.

Balita pendek (stunting) dapat diketahui bila seorang balita sudah diukur panjang atau tinggi badannya, lalu dibandingkan dengan standard dan hasilnya berada di bawah normal (<-2 SD s.d -3 SD). Hal tersebut bisa disebabkan karena kekurangan gizi baik dalam masa kehamilan maupun pada masa bayi, seperti yang dijelaskan oleh Pusat Data dan Informasi Kementrian Kesehatan RI tahun 2016 yang menyatakan bahwa masalah balita pendek menggambarkan adanya masalah gizi kronis, dipengaruhi dari kondisi ibu/calon ibu, masa janin, dan masa bayi/balita, termasuk penyakit yang diderita selama masa balita. Menurut prevalensi status gizi dengan kategori sangat pendek pada balita berdasarkan pengukuran Tinggi Badan menurut Umur (TB/U) tahun 2013 secara nasional terdapat 42.82\%7. Hal ini tidak sesuai dengan hasil penelitian ini karena tidak terdapat balita dengan kategori "sangat pendek". Tidak adanya balita dengan kategori sangat pendek dari hasil penelitian bisa disebabkan karena gizi yang disediakan oleh orang tua balita sudah tercukupi dalam segi jumlah dan jenis gizi, seperti Calsium, Vitamin D, Zat Besi, Protein, dan lain-lain. Hal ini didukung oleh Nimas Mita Etika yang menyatakan bahwa salah satu faktor yang mempengaruhi pertumbuhan anak adalah zat gizi yang didapatkan dari makanan yang dimakan oleh anak. Tidak ada zat gizi yang bisa bekerja sendiri untuk memaksimalkan pertumbuhan anak, semua memiliki perannya masing-masing. Sehingga, anak membutuhkan berbagai macam zat gizi agar proses pertumbuhannya bisa berjalan dengan normal dan cepat. Namun pada hasil penelitian ini masih terdapat balita dengan kategori "pendek" (4.9\%). Hal ini didukung oleh Riset Kesehatan RI tahun 2015 yang menyatakan bahwa di Jawa Barat terdapat balita dengan kategori "sangat pendek" sebanyak $6.9 \%$ dan kategori "pendek" sebanyak $18.1 \%$.

Berdasarkan tabel 1 diketahui balita dengan status pertumbuhan baik terdapat $87.8 \%$ dimana hasil tersebut didapatkan apabila BB/U, TB/U, dan Lingkar Kepala (LK) dalam kategori normal. Sedangkan terdapat $12.2 \%$ balita dengan status pertumbuhan kurang baik, yang dilihat berdasarkan ada salah satu atau lebih BB/U, TB/U, atau Lingkar Kepala (LK) memiliki kategori di bawah normal (pendek, sangat pendek, kurus, atau sangat kurus). Pertumbuhan merupakan perubahan ukuran fisik dari waktu ke waktu, baik dalam segi dimensi, proporsi, maupun komposisi atau yang lebih dikenal dengan sebutan antopometri. Sehingga penulis menyatakan bahwa mayoritas pertumbuhan balita di wilayah kerja puskesmas Parung Panjang dalam kategori baik karena pada penelitian ini terdapat balita dengan status pertumbuhan baik sebanyak $36(87,8 \%)$ lebih banyak dibanding status pertumbuhan kurang baik sebanyak $(12.2 \%)$. Pada hasil penelitian ini, balita dalam kategori pertumbuhan baik bisa disebabkan karena nutrisi yang didapat sudah baik sehingga bisa menimbulkan pertumbuhan yang baik pula. Hal ini didukung teori yang dikemukakan oleh Salim Choiri yang menyebutkan bahwa intake nutrisi yang baik dan seimbang, pemeliharaan kesehatan yang baik, pola pengasuhan yang baik, serta kondisi lingkungan yang bersih dan sehat, dan lain-lain dapat mempengaruhi pertumbuhan dan perkembangan 
balita. Pertumbuhan balita yang baik bisa dikatakan apabila seorang balita yang bertamabah usia, maka akan bertambah pula berat badannya, tinggi badannya, maupun lingkar kepalanya dalam batas yang normal sesuai dengan usianya. ${ }^{8} \mathrm{Hal}$ ini didukung teori oleh Rohan dan Siyoto yang menyatakan bahwa pertumbuhan adalah proses yang dinamis dan terus menerus dan bertambahnya besarnya sel di seluruh bagian tubuh. ${ }^{9}$

Berdasarkan tabel 1 diketahui status perkembangan menggunakan Kuesioner Pra Skrining Perkembangan (KPSP) dengan kategori sesuai (9-10) terdapat 90.2\% sedangkan kategori meragukan terdapat 9.8\%. Menurut UNICEF tahun 2011 didapat data masih tingginya angka kejadian gangguan pertumbuhan dan perkembangan pada anak usia balita khususnya gangguan perkembangan motorik didapatkan $(27,5 \%)$ atau 3 juta anak mengalami gangguan. Balita di Indonesia Sekitar $16 \%$ di laporkan mengalami gangguan perkembangan berupa gangguan kecerdasan akibat gangguan perkembangan otak, gangguan pendengaran dan gangguan motorik ${ }^{5}$. Pada tahun 2010 gangguan pertumbuhan dan perkembangan pada anak di Indonesia mencapai $35,7 \%$ dan tergolong dalam masalah kesehatan masyarakat yang tinggi menurut acuan $\mathrm{WHO}$ karena masih diatas $30 \%^{7}$. Data angka kejadian keterlambatan perkembangan umum belum diketahui dengan pasti, namun diperkirakan sekitar 1-3\% anak di bawah usia 5 tahun mengalami keterlambatan perkembangan umum yang disebabkan oleh gangguan genetik atau kromosom seperti sindrom Down; gangguan atau infeksi susunan saraf seperti palsi serebral atau CP, spina bifida, sindrom Rubella; riwayat bayi risiko tinggi seperti bayi prematur atau kurang bulan, bayi berat lahir rendah, bayi yang mengalami sakit berat pada awal kehidupan sehingga memerlukan perawatan intensif dan lainnya. ${ }^{3}$

Menurut survei yang dilakukan di Puskesmas Parung Panjang dengan capaian ASI Eksklusif program gizi pada tahun 2016 yang targetnya 90\%, namun hanya tercapai $35.77 \%$ dan kesenjangannya $54.23 \%$. Sementara untuk cakupan ASI, pemerintah berharap jumlah tersebut mencapai $80 \%$ pada 2019 . Saat ini cakupan ASI baru mencapai $63 \%$. Pemberian ASI eksklusif untuk bayi yang berusia $<6$ bulan secara global dilaporkan kurang dari $40 \%$. Secara nasional cakupan ASI untuk bayi sampai umur 6 bulan mengalami fluktuasi, yaitu 24,3\% pada tahun 2008, kemudian meningkat pada tahun 2009 menjadi $34,3 \%$ dan menurun pada tahun 2010 menjadi $33,0 \%$.

Berdasarkan paparan yang ada di atas, jumlah capaian ASI eksklusif di Puskesmas Parung Panjang (35,77\%) turut menyumbang angka kesenjangan bagi cakupan secara global (kurang dari 40\%). Beberapa kepercayaan terdahulu atau mitos menyebutkan bahwa ibu yang bekerja tidak dapat memberikan ASI eksklusif, serta ibu yang mengetahui tentang pentingnya memberikan ASI dibanding susu formula, namun mereka merasa khawatir bila bayinya tidak diberi susu botol maka bayinya tidak bisa menjadi gemuk, atau tidak bisa cepat naik berat badannya seperti yang mereka harapkan, yang ada di lokasi penelitian ini bisa menyebabkan terhambatnya pemberian ASI secara eksklusif sehingga capaian ASI eksklusif berkurang dan tidak sampai di angka target $(90 \%)$. Faktor yang menyebabkan pemberian ASI eksklusif tidak optimal, antara lain karena faktor si ibu sendiri, tenaga kesehatan, produsen susu formula, penyelenggara pelayanan kesehatan dan mitos-mitos pemberian ASI eksklusif. Turut menyumbangnya angka di atas menyebabkan dampak pada cakupan capaian ASI eksklusif secara global, sehingga kesenjangan capaian ASI eksklusif menjadi bertambah. Akan tetapi menurut hasil penelitian di wilayah kerja Puskesmas 
Parung Panjang khususnya di Posyandu Bakti Husada terdapat $68.3 \%$ capaian bayi 0-6 bulan yang diberikan ASI eksklusif, hal ini terdapat perbedaan antara capaian secara global dan capaian yang didapat dari hasil penelitian ini $^{3}$.

Hasil dari penelitian yang dilakukan Siti Nurjanah (2015) ibu yang memberikan ASI secara eksklusif dan tumbuh kembang balitanya baik terdapat $85,71 \%$, sedangkan menurut penelitian ini yang diberikan ASI secara eksklusif dan tumbuh kembang balitanya baik terdapat $97.0 \%$. Hal ini menunjukkan bahwa di wilayah kerja Puskesmas Parung Panjang memiliki capaian lebih tinggi daripada penelitian yang dilakukan oleh Siti Nurjanah. Menurut Pusponegoro, anak yang mendapat ASI jauh lebih matang, lebih asertif, dan memperlihatkan progresifitas yang lebih baik pada skala perkembangan dibandingkan anak yang tidak mendapat ASI. Bayi yang mendapat ASI 4- 6 bulan lebih jarang mengalami keterlambatan perkembangan bicara dan motorik ${ }^{6}$. Hal ini sesuai bahwa keuntungan dari pemberian ASI eksklusif adalah bayi mengalami pertumbuhan dan perkembangan yang sesuai dengan umur, terbentuknya ikatan batin yang kuat, serta meminimalkan risiko bayi terserang penyakit pencernaan, pernafasan, dan lain-lain ${ }^{7}$.

Dari hasil paparan di atas, berdasarkan manfaat ASI menurut Dyah Umiyarni 2017 yang mengungkapkan bahwa ASI eksklusif dapat meningkatkan kecerdasan dan ASI eksklusif dapat menjamin tercapainya pengembangan potensi kecerdasan anak secara optimal, sehingga penulis menyimpulkan bahwa ASI eksklusif dapat berefek langsung dengan tumbuh kembang ${ }^{10}$.

\section{SIMPULAN DAN SARAN}

Adapun simpulan yang diperoleh dari penelitian ini tentang hubungan antara Air Susu lbu (ASI) dan faktor keluarga terhadap tumbuh kembang balita di wilayah kerja Puskesmas Parung Panjang bahwa Distribusi frekuensi pertumbuhan pada balita masih terdapat $5(12.2 \%)$ dengan kategori kurang, Serta distribusi frekuensi perkembangan pada balita $4(9.8 \%)$ yang memiliki perkembangan meragukan. Distribusi frekuensi pemberian ASI eksklusif pada balita terdapat $28(68.3 \%)$ serta terdapat hubungan anatara ASI eksklusif terhadap tumbuh kembang balita.

Saran Untuk Orang Tua untuk memberikan ASI secara ekslusif, disamping itu memberikan stimulasi yang cukup sesuai dengan usia. Untuk Tenaga Kesehatan diharapkan tenaga kesehatan mampu meningkatkan upaya promotif Seperti penyuluhan tentang pentingnya ASI ekslusif dan peran keluarga dalam menstimulasi tumbuh kembang balita. Untuk Peneliti Lain diharapkan bisa melanjutkan penelitian dengan menggunakan variabel lain yang dapat mempengaruhi pertumbuhan dan perkembangan balita.

\section{KETERBATASAN PENELITIAN}

Berdasarkan hasil dan pembahasan, peneliti mengungkapkan keterbatasan penelitian lainnya yaitu masih ada beberapa faktor yang belum sempat terkaji, seperti balita yang sudah mengikuti kelompok belajar atau dengan Pendidikan Anak Usia Dini (PAUD), menurut hasil penelitian yang dilakukan oleh Yeni rahma responden yang menggunakan PAUD memiliki kecenderungan tumbuh kembang sesuai KPSP sebesar 3,3 kali lebih besar dibandingkan dengan responden yang tidak menggunakan PAUD $^{3}$. Pencapaian tumbuh kembang anak tak pernah lepas dengan stimulasi yang tersedia dilingkungan anak. Sesuai dengan keberadaannya, PAUD merupakan 
lingkungan yang direkayasa secara terstruktur agar menjadi lingkungan bermain anak sekaligus sebagai tempat belajar. Kurikulum dan metode yang digunakan memungkinkan anak mendapatkan beragam stimulasi yang mendukung seluruh aspek tumbuh kembangnya. Beberapa studi membuktikan bahwa stimulasi yang diberikan dengan baik sesuai usianya maka anak akan mendapatkan pencapaian tumbuh kembang yang sesuai.

Pada pemeriksaan menggunakan Kuesioner Pra Skrining Perkembangan (KPSP) apabila terdapat perkembangan yang meragukan (skor 7-8) atau menyimpang (skor $<6$ ) seharusnya dilakukan pemeriksaan lanjutan 2 minggu kemudian. Namun karena adanya keterbatasan waktu, pemeriksaan lanjutan tersebut tidak dilaksanakan.

\section{DAFTAR PUSTAKA}

1. Kemenkes RI. Kinerja Kegiatan Pembinaan Gizi Tahun 2011. Jakarta : s.n., 2011.

2. Widiyani, Roshma. SDG's Fokus Perbaiki Gizi. s.I. : Harian Nasional, 2015.

3. Yeni, Sri Rahma. Hubungan Status Gizi dan Pola ASuh Orang Tua dengan Perkembangan Anak Usia Prasekolah di TK Melati Ikhlas Kota Padang. Sumatera Barat : s.n., 2015.

4. WHO. Infant Feeding Recommendation [serial online]. 2008.

5. Kemenkes RI. Kinerja Kegiatan Pembinaan Gizi Tahun 2011. Jakarta : 2011.

6. Kemenkes RI. Stimulasi, Deteksi, dan Intervensi Dini Tumbuh Kembang Anak. Jakarta : Departemen Kesehatan, 2010.

7. Rahardjo, Marmi dan. Asuhan Neonatus, Bayi, Balita, dan Anak Prasekolah. Yogyakarta : Pustaka Pelajar, 2012.

8. WHO. Infant Feeding Recommendation [Serial Online]. 2008.

9. Yeni, Sri Rahma. Hubungan Status Gizi dan Pola Asuh Orang Tua dengan Perkembangan Anak Usia Prasekolah di TK Melati Ikhlas Kota Padang. Padang, Sumatera Barat : s.n., 2015.

10. Widiyani, Rosmha. Harian Nasional. Lima Fokus Penanganan Gizi Tahun 2017. 2017.

11. Milda, Novita Susanty. Hubungan Derajar Stunting, Asupan Gizi, dan Sosial Ekonomi Rumah Tangga dengan Perkembangan Motorik Anak Usia 24-36 Bulan di Wilayah Kerja Puskesmas Bugangan Semarang. Semarang : Universitas Diponegoro, 2012.

12. Ribka, Lani Karundeng, dkk. Hubungan Jarak Kelahiran dan Jumlah Anak dengan Status Gizi Balita di Puskesmas Kao Kecamatan Kao Kabupaten Halmahera Utara. 1, Halmahera Utara : eJournal Keperawatan, 2015, Vol. 3.

13. Widiyani, Rosmha. Harian Nasional. SDG's Fokus Perbaiki Gizi. 2015.

14. Riyanti, Fina dan Lilik Hanifah. Hubungan Pemberian ASI Eksklusif dengan Perkembangan Bayi Usia 6-12 Bulan di Desa Carikan Juwiring Klaten Tahun 2013. Klaten : Jurnal Ilmiah Kesehatan, 2013, Vol. 8.

15. Fitri, Dian Insana, dkk. Hubungan Pemberian ASI dengan Tumbuh Kembang Bayi Umur 6 Bulan di Puskesmas Nanggalo. Padang : s.n., 2014, Vol. 3.

16. Ariani, dan Mardhani Yosoprawoto. Usia Anak dan Pendidikan Ibu sebagai Faktor Risiko Gangguan Perkembangan Anak. Malang : s.n., 2012, Vol. 27.

17. Kemenkes RI. Stimulasi, Deteksi, dan Intervensi Dini Tumbuh Kembang Anak. Jakarta : Departemen Kesehatan, 2010.

18. Kementrian Kesehatan RI. Pedoman Pelaksanaan Stimulasi, Deteksi, dan Intervensi Dini Tumbuh Kembang Anak di Tingkat Pelayanan Kesehatan Dasar. Jakarta : Departemen Kesehatan, 2012.

19. Nurjanah, Siti. ASI Eksklusif Meningkatkan Perkembangan Bayi Usia 6-12 Bulan di Wilayah Kerja Puskesmas Banyu Urip Surabaya. Surabaya : s.n., 2015, Vol. 8.

20. Purnamasari, Dyah Umiyarni. ASI Eksklusif. Unsoed : s.n., 2011. 